\title{
APLIKASI TRICHOKOMPOS DAN PUPUK GRAND-K TERHADAP PERTUMBUHAN DAN HASIL BAWANG MERAH (Allium ascalonicum L.) PADA LAHAN GAMBUT RAWAN TERENDAM
}

\author{
(Application of Trichocompost and Grand-K Fertilizer on the Growth and Yield of \\ Shallot (Allium ascalonicum L.) on Prone to Submerged Peat Soil) \\ SELVIA SUTRIANA ${ }^{1 *}$, SARIPAH ULPAH ${ }^{1}$, M. NUR $^{1}$ \\ ${ }^{1}$ Program studi Agroteknologi Fakultas Pertanian Universitas Islam Riau \\ JI. Kaharuddin Nasution 113, Pekanbaru, Riau \\ *Email: selviasutriana@agr.uir.ac.id
}

\begin{abstract}
Riau is a province in Sumatra Island with the widest peatland covering up to $\pm 4,04$ million Ha or about $56,1 \%$ of the area, with various types of peat, including the potentially submerged peat area. With the peat charasteristics drawbacks such as low nutrient content and relatively high acidity, cause this type of land barely cultivated for horticulture crop such as shallot. Therefore, efforts are needed to make use of peat land for this type of commodity by overcoming the shortages. This research thus aimed at evaluating the growth and yield of shallot in potentially submerged peat soil, treated with Trichocompost and Grand-K Fertilizer. Experiment was conducted on peat soil prone to submerged. in Labersa Street Simpang tiga village, Bukit Raya subdistrict, Pekanbaru city. for four months from September to December 2019. The experiment was arranged in completely randomized design with two factors; each at four levels. The factors were Trichocompost (at 0, 2, 4, 6 ton ha ${ }^{-1}$ ) and Grand $K$ fertilizer (at 0,50,100,150 kg ha ${ }^{-1}$ ). The parameters observed were the percentage of seed viability, plant height, number of leaf, number of tuber, and the yield per plant. It was found that application of trichocompost combined with Grand $K$ fertilizer resulted in better root system, enabling the plants submerged for about 30 days to resume the vegetative growth. Results of the experiment showed that the best combination of treatment was Trichokompos at $4-6$ ton ha-1 dan Grand $\mathrm{K}$ at $150 \mathrm{~kg} \mathrm{ha}^{-1}$.
\end{abstract}

Keywords: grand K, shallod, submerged peat, trichocompost

\section{PENDAHULUAN}

Provinsi Riau memiliki lahan gambut terluas di Pulau Sumatera yaitu $\pm 4,04$ juta $\mathrm{Ha}$ atau $56,1 \%$ dari luas total lahan gambut di Sumatera (Wahyunto et al., 2003), pemanfaatannya sebagian besar digunakan untuk perkebunan kelapa sawit dan kayu kertas yang diperkirakan telah merusak lahan gambut dengan segala fungsi ekologisnya. Lahan gambut dikelolah dengan baik dan benar berpotensi besar dalam budidaya tanaman hortikultura tanpa merusak fungsi alami lahan gambut itu sendiri, salah satunya budidaya tanaman bawang merah yang dibutuhkan sehari-hari dalam kehidupan masyarakat untuk semua jenis bumbu masakan, industri atau kesehatan (Ismawati dan Hamidy, 2012).

Tanah gambut memiliki kelebihan air yang berdampak pada kurangnya oksigen $\left(\mathrm{O}_{2}\right)$ sehingga menghambat pertumbuhan akar, dan menyebabkan tanaman mudah rebah, miskin hara, bahkan tanaman bawang merah mudah terserang layu fusarium dan busuk umbi, akibatnya produksi rendah atau gagal panen.
Salah satu cara untuk meningkatkan kesuburan tanah gambut dan meningkatkan produksi serta mencegah tanaman terserang layu fusarium dan busuk umbi adalah dengan pemberian pupuk organik, yaitutrichokompos dan mengkombinasikan dengan pupuk anorganik yaitu pupuk Grand-K.

Trichokompos adalah bahan organik yang telah dikomposkan dengan menggunakan Trichoderma sp. sebagai mikroba dekomposer. Trichokompos dapat memperbaiki sifat biologi, fisik, dan kimia tanah, sehingga tanaman dapat tumbuh lebih baik dan lebih tahan terhadap serangan pathogen. Penggunaan Trichoderma sp. saat pengomposan dapat mempercepat proses pengomposan dan memperbaiki kualitas kompos yang dihasilkan, karena cendawan ini dapat menghasilkan tiga enzim yaitu enzim celobiohidrolase $(\mathrm{CBH})$ yang aktif merombak selulosa alami, enzim endoglikonase yang aktif merombak selulosa terlarut dan enzim glokosidase yang aktif menghidrolisis unit selobiosa menjadi molekul glukosa.

Dalam meningkatkan kualitas dan produksi umbi bawang merah maka perlu 
ditambahkan pupuk anorganik sesuai dosis, salah satunya pupuk Grand-K yang merupakan pupuk majemuk dengan kandungan $\mathrm{K} 2 \mathrm{O}$ yang siap diserap tanaman mencapai $46 \%$. Pupuk Grand K berfungsi dalam pembentukan umbi dan buah menjadi lebih berisi, mengurangi pembusukan umbi, bebas chlor $(\mathrm{Cl})$ sehingga tidak menyebabkan terjadinya keracunan pada tanah, ketahanan terhadap penyakit dan panen dapat dilakukan serentak.

\section{BAHAN DAN METODE}

Penelitian ini dilaksanakan di Lahan Gambut Masyarakat, Jalan Parit Indah Kelurahan Simpang Tiga Kecamatan Bukit raya Kota Pekanbaru Provinsi Riau, dari bulan September sampai Desember 2019. Bahan bahan yang digunakan: bibit bawang merah varietas Bima Brebes, trichoderma, kompos sisa tanaman jagung, pupuk grand K, NPK 16:16:16, dolomit, dithane M45. Sedangkan alat-alat yang digunakan dalam penelitian ini adalah hand tracktor, cangkul, meteran, handsprayer, gembor, kamera, dan alat-alat tulis.

Penelitian menggunakan rancangan acak lengkap faktorial, terdiri dari 2 faktor yaitu dosis Trichokompos $(T)$ dengan 4 taraf : 0,2 , 4, 6 ton ha ${ }^{-1}$ dan pupuk Grand K $(\mathrm{K})$ dengan 4 taraf: $0,50,100,150 \mathrm{~kg} \mathrm{ha}^{-1}$, masing-masing terdapat 3 ulangan dengan 16 tanaman per plot dan 8 tanaman dijadikan sampel. Total keseluruhan 768 tanaman.

Pelaksanaan penelitian dimulai dari persiapan lahan penelitian dengan luas $15 \mathrm{~m} \mathrm{x}$ $7,5 \mathrm{~m}$, ukuran plot $1 \mathrm{~m} \times 1 \mathrm{~m}$ sebanyak 48 plot, selanjutnya pengukuran $\mathrm{pH}$ tanah, dimana diperoleh 4,3, persiapan Bibit bawang merah, Trichokompos dan grand K. Penanaman pada sore hari dengan jarak tanam $25 \times 25 \mathrm{~cm}$ dan pemberian Trichokompos seminggu sebelum penanaman dan Pupuk Grand-K diberikan 2 kali $(1 / 2$ dosis saat penanaman dan $1 / 2$ dosis saat 30 hari setelah tanam (hst). Pupuk NPK 16:16:16 diberikan 2 kali, yaitu $15 \mathrm{~g}$ per plot saat penanaman dan $15 \mathrm{~g}$ per plot selanjutnya saat $30 \mathrm{hst}$. Pemeliharaan (penyiraman dan pengendalian hama dan penyakit tanaman), Panen dilakukan secara serentak pada umur 75 hst, proses pertumbuhan dan produksi umbi lambat dikarenakan tanaman terendam banjir.

Parameter pengamatan yang diamati yaitu persentase daya tumbuh dihitung umur 7 hari setelah tanam dengan cara menghitung jumlah bibit yang sudah tumbuh per plot dibagi dengan jumlah bibit keseluruhan kali 100\%, tinggi tanaman diukur 3 kali yaitu umur 7, 21 dan 35 hari setelah tanam, jumlah daun diamati umur 30 hari setelah tanam, persentase terbentuk umbi diamati umur 30 hari setelah tanam dengan cara menghitung umbi yang sudah mulai terbentuk per plot dibagi jumlah umbi per plot kali 100\%, persentase umbi membesar dihitung saat tanaman berumur 50 hari setelah tanam, jumlah umbi dihitung selesai pemanenan, dan berat umbi per tanaman dihitung setelah umbi dipanen dan dikering anginkan selama 1 minggu.

\section{HASIL DAN PEMBAHASAN Persentase daya tumbuh}

Hasil pengamatan terhadap persentase daya tumbuh bawang merah umur 7 hst menunjukkan bahwa tidak ada pengaruh interaksi berbagai dosis trichokompos dan pupuk grand $\mathrm{K}$ terhadap pertumbuhan dan hasil bawang merah (Gambar 1).

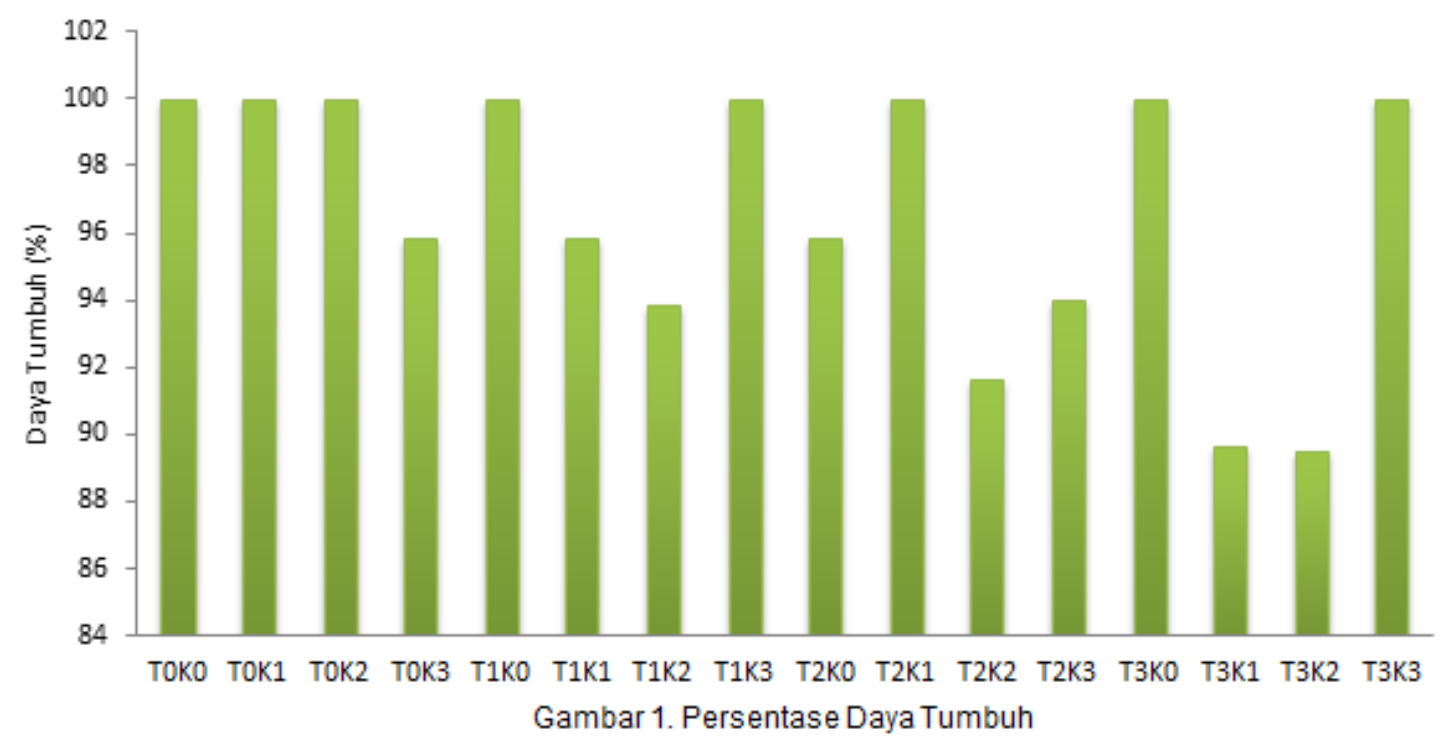


Persentase daya tumbuh bawang merah umur 7 hst rata-rata sudah mencapai $96,6 \%$, artinya bibit bawang merah yang digunakan tergolong bibit unggul, dimana suatu benih dikatakan unggul apabila memiliki persentase daya tumbuh minimal $80 \%$ dan didukung oleh tingkat kesuburan tanah. Pada umur $7 \mathrm{hst}$, perlakuan trichokompos dan grand $\mathrm{K}$ yang diberikan belum mempengaruhi terhadap pertumbuhan bawang merah karena masih tersedia pada bibit, sehingga tanaman

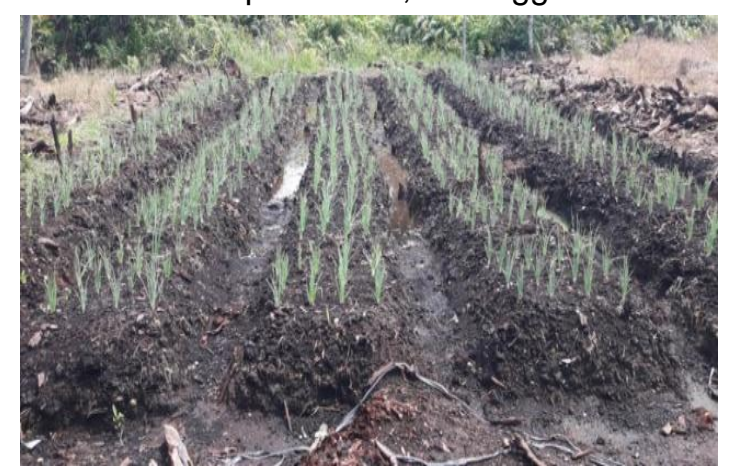

Gambar 2. Kondisi lahan penelitian sebelum dan sesudah terendam

\section{Tinggi Tanaman}

Hasil pengamatan terhadap parameter tinggi tanaman bawang merah pada umur 7, 21 dan 35 hst setelah dianalisis ragam menunjukkan bahwa pengaruh interaksi berbagai dosis trichokompos dan pupuk grand tanpa perlakuan dan diberi perlakuan hasilnya sama.

Daya tumbuh dapat diartikan kemampuan tumbuh bibit dalam jangka waktu tertentu, artinya bibit tersebut mempunyai kemampuan tumbuh secara normal dan sehat dalam jangka waktu seumur pertumbuhan dan perkembangbiakannya. Bibit merupakan faktor genetik tanaman yang sangat mempengaruhi terhadap pertumbuhan dan produksi tanaman.

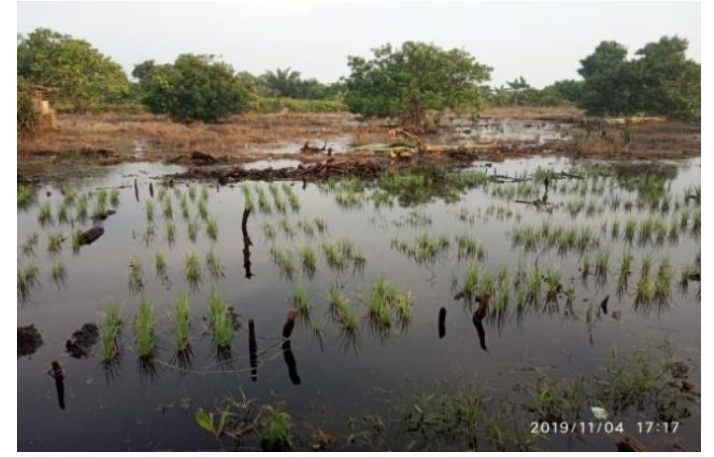

$\mathrm{K}$ nyata pada umur 21 hst. Pengaruh utama trichokompos nyata pada umur 21 dan $35 \mathrm{hst}$, sedangkan pengaruh utama grand $\mathrm{K}$ nyata pada umur 21 hst. Rerata tinggi tanaman umur 7, 21 dan 35 hst dapat dilihat pada Gambar 3.

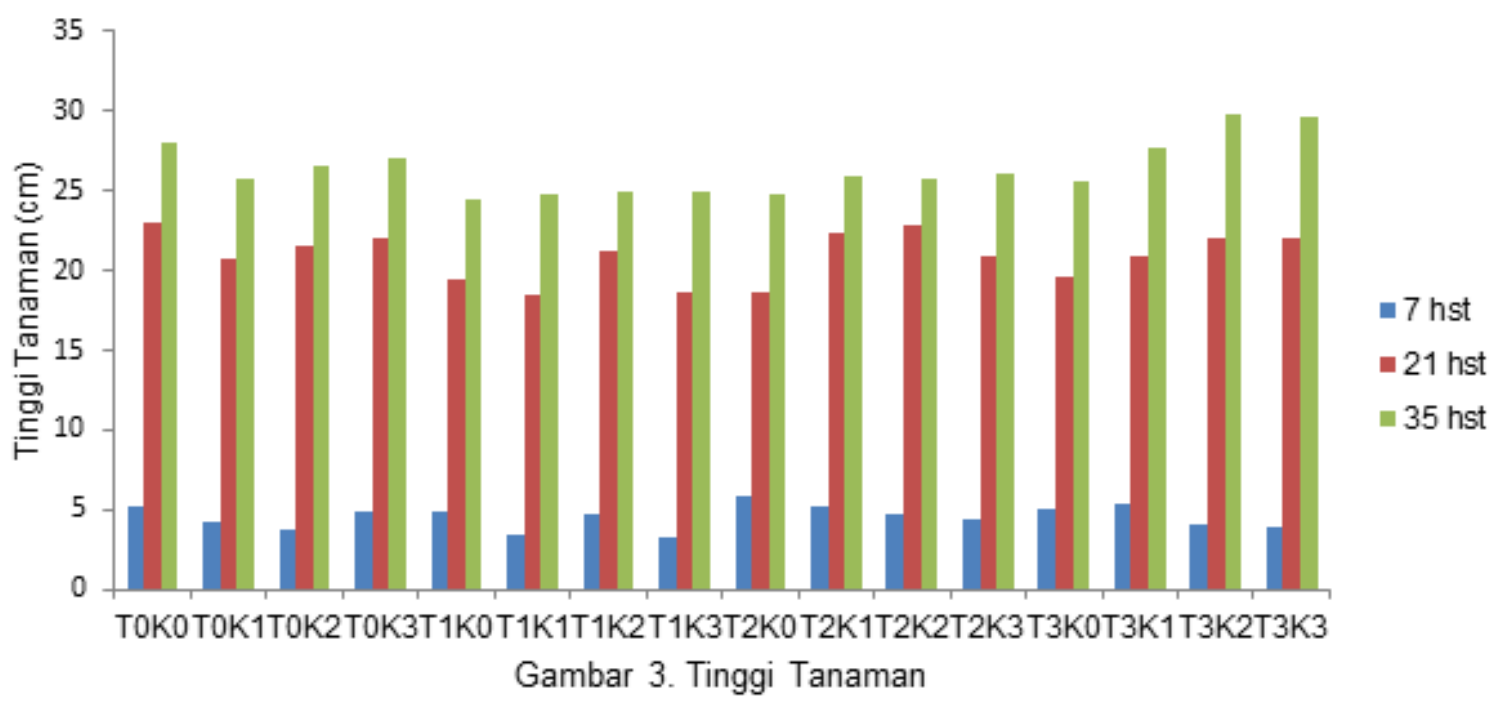

Pada Gambar 3 dapat dilihat bahwa tinggi tanaman umur 7 hst rata-rata $4,59 \mathrm{~cm}$, umur 21 hst tinggi tanaman rata-rata $20,90 \mathrm{~cm}$ dan 35 hst tinggi tanaman rata-rata $26,34 \mathrm{~cm}$. Pada umur 7-21 hst pertambahan tinggi tanaman cepat/laju, tetapi pada umur $35 \mathrm{hst}$ pertambahan tinggi tanaman rendah, hal ini dikarena lahan sudah terendam banjir lebih kurang 30 hari sehingga menyebabkan tinggi tanaman rendah bahkan terhenti.

Jika dibandingkan dengan deksripsi bima brebes, hasil yang diperoleh ini rendah, walaupun diketahui bibit bima brebes termasuk varietas yang dapat menyesuaikan dengan kondisi lingkungan, dimana bibit tumbuh dan berkembang, selama masih dalam batas-batas lingkungan tumbuh kembangnya. Hal yang terjadi dilapangan lahan terendam sudah melebihi batas untuk budidaya tanaman bawang merah. Curah hujan tinggi dan ditambah lahan terendam dapat menyebabkan unsur hara tercuci sehingga kurang termanfaatkan oleh tanaman.

Tanaman yang diberikan Trichoderma dan dikombinasikan dengan pupuk Grand K memiliki sistem perakaran yang lebih baik 
ditandai dengan tanaman yang terendam (Gambar 2) lebih kurang 30 hari masih mampu mempertahankan pertumbuhan vegetatifnya. Peningkatan pertumbuhan dapat meningkatkan kemampuan penyerapan air dan hara tanaman dalam fase pertumbuhan vegetatif. Sedangkan menurut Setyobudi dalam Rochyat (2017) Trichoderma berfungsi sebagai dekomposer bahan organik, sekaligus meningkatkan produktifitas tanaman, dan pengendali OPT penyakit tular tanah. Sedangkan kompos juga sangat berperan dalam proses pertumbuhan tanaman. Kompos tidak hanya menambah unsur hara, tetapi juga menjaga fungsi tanah sehingga tanaman dapat bertumbuh dengan baik. Sejalan dengan pendapat Ichwan (2007) bahwa pemberian trichocompos diduga lebih cenderung memperbaiki sifat fisik dan biologi tanah, disamping itu trichoderma dapat pula berfungsi sebagai agen hayati dan stimulator pertumbuhan tanaman (Nurahmi dkk., 2012).

\section{Jumlah Daun}

Hasil pengamatan terhadap parameter pengamatan jumlah daun bawang merah (Gambar 4), setelah dianalisis ragam menunjukkan bahwa pengaruh interaksi dan utama berbagai dosis trichokompos dan pupuk grand $\mathrm{K}$ terhadap pertumbuhan dan hasil bawang merah nyata.

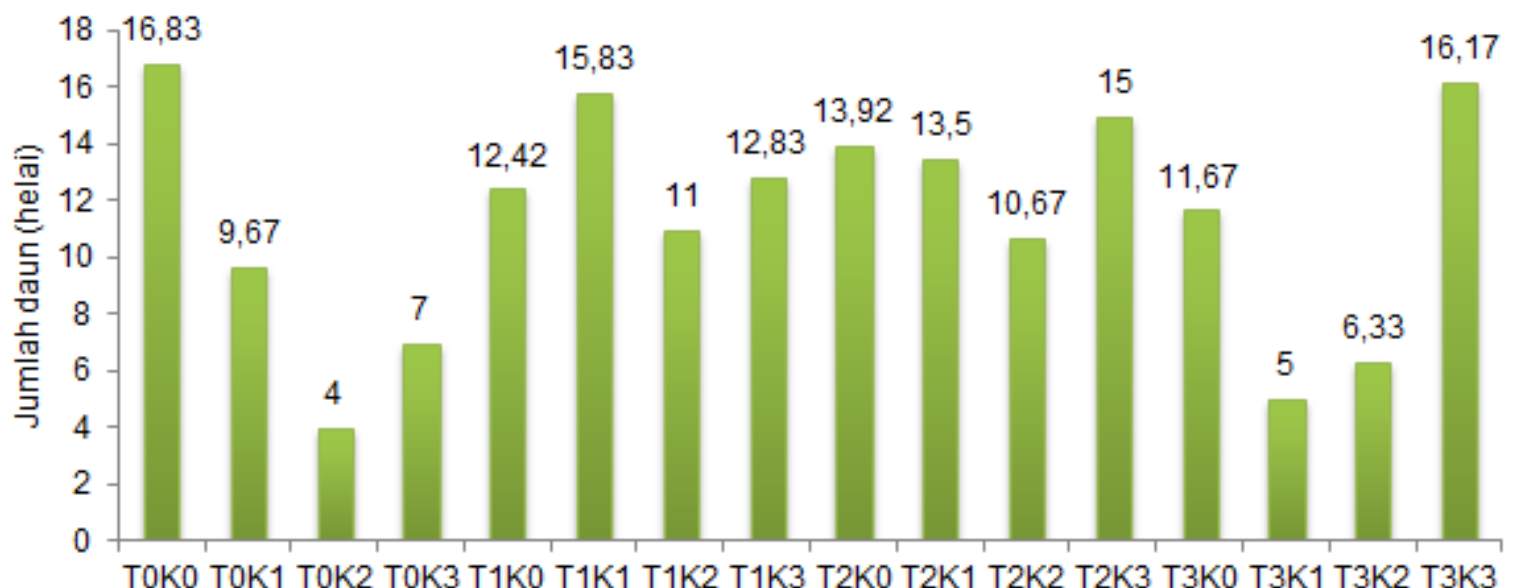

Gambar 4. Jumlah daun

Pada Gambar 4 dapat dilihat bahwa rerata jumlah daun terbanyak terdapat pada perlakuan TOKO (tanpa perlakuan) 16.83 helai. Tinggi hasil rerata jumlah daun pada tanpa pemberian perlakuan di duga karena bibit yang digunakan adalah bibit yang unggul, juga pengelolaan tanah gambut yang dilakukan sebelum penelitian sudah sangat maksimal sehingga tanah menjadi gembur, udara didalam tanah menjadi lebih baik sehingga mempermudah gas-gas oksigen masuk ke dalam tanah sedangkan gas-gas yang meracuni akar tanaman dapat beroksidasi serta asam-asam dapat keluar dari dalam tanah. Pengolahan tanah yang baik juga menjadikan akar tanaman dapat bergerak dengan bebas dalam penghisapan zat-zat makanan. Jumlah daun yang diperoleh ini masih rendah dibandingkan dengan deksripsi yaitu 16 - 49 helai, dan jika dibandingkan dengan penelitian Sutriana dan Saripah (2018) jumlah daun yang diperoleh 15 - 40 helai. Rendahnya hasil yang diperoleh ini dikarenakan lahan gambut yang digunakan terendam banjir lebih kurang $15 \mathrm{~cm}$ pada umur 21 - 50 hari setelah tanam sehingga menyebabkan pertumbuhan bawang merah terganggu, salah satunya jumlah daun sedikit dan menguning.

\section{Persentase Pembesaran Umbi}

Parameter pembesaran umbi diamati umur 50 hari setelah tanam. Dilakukannya pengamatan ini untuk melihat berapa persen tanaman bawang merah yang sudah terjadi pembesaran pada umur 50 hari setelah tanam, hal ini dikarenakan keseluruhan tanaman terendam banjir sehinga menyebabkan pertumbuhan dan perkembangan tanaman bawang merah terhambat. Hasil pengamatan terhadap parameter persentase umbi membesar setelah dianalisis ragam menunjukkan bahwa pengaruh interaksi dan utama berbagai dosis trichokompos dan pupuk grand $\mathrm{K}$ nyata.

Pada Gambar 5 dapat dilihat bahwa rata-rata persentase umbi yang telah membesar umur 50 hst adalah 51,04\% dan hasil terbaik pada perlakuan Trichokompos $600 \mathrm{~g} / \mathrm{plot}$ dan grand $\mathrm{K}$ dosis $15 \mathrm{~g} /$ plot (T3K3) yaitu $83,33 \%$. Tingginya hasil persentase pada perlakuan ini karena unsur hara yang dibutuhkan tanaman tercukupi dan kemungkinan tidak semua unsurhara tercuci 
oleh air hujan sehingga masih ada yang dapat di serap oleh tanaman untuk pertumbuhan dan perkembangannya. Hasil ini lebih mungkin sedikit dibandingkan dari penelitian-penelitian sebelumnya karena dipengaruhi oleh curah hujan yang tinggi menyebabkan pupuk Trichokompos dan Grand $\mathrm{K}$ yang sudah diberikan tidak berfungsi untuk perkembangan dan pembesaran umbi.

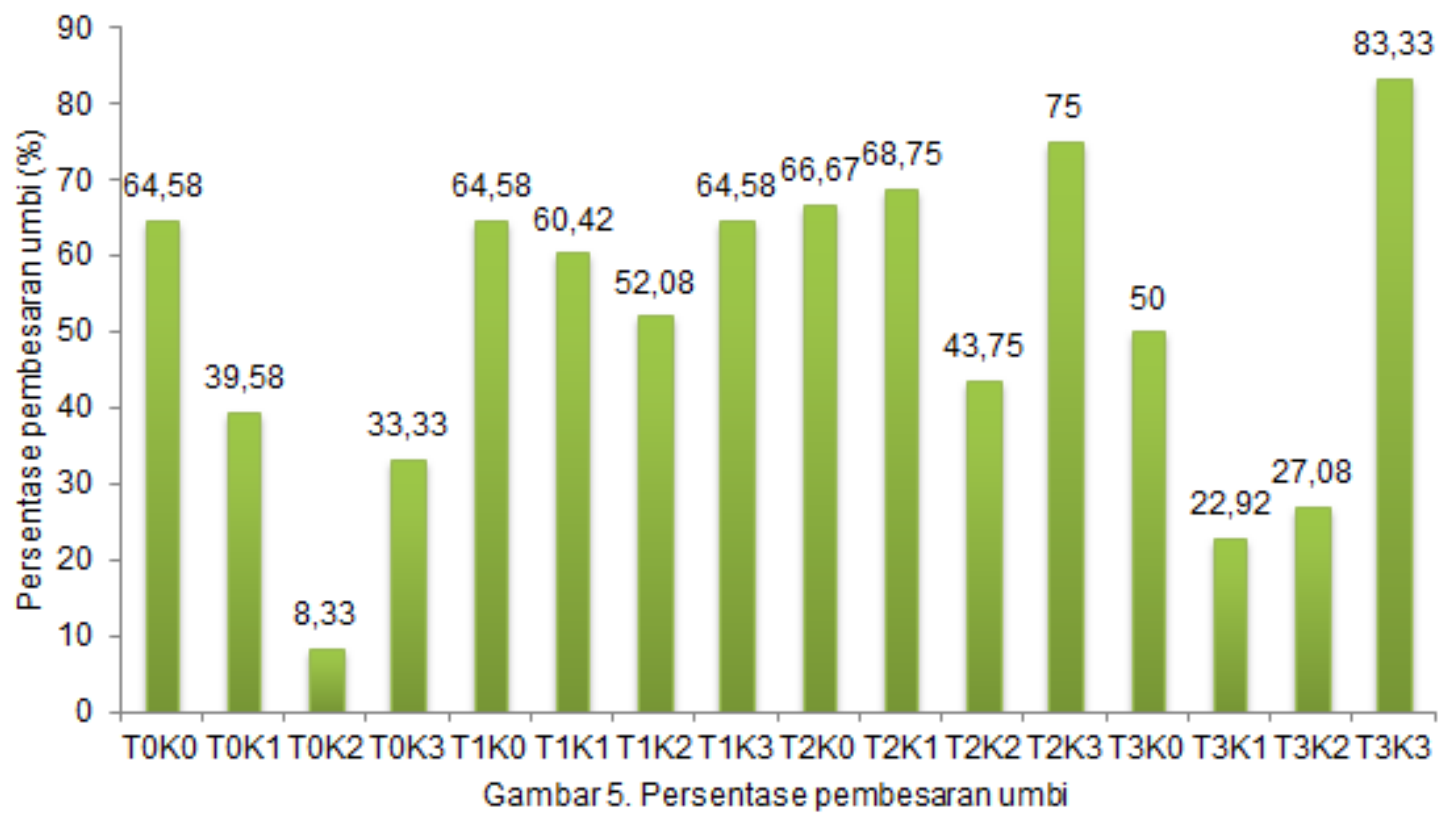

\section{Jumlah Umbi}

Hasil pengamatan terhadap parameter Jumlah umbi per tanaman setelah dianalisis ragam menunjukkan bahwa pengaruh interaksi berbagai dosis trichokompos dan pupuk grand $\mathrm{K}$ nyata. Jumlah umbi tanaman bawang dapat dilihat pada tabel dibawah ini. Pada Gambar 6 dapat dilihat bahwa perlakuan terbaik untuk menghasilkan jumlah umbi terbanyak adalah Trichokompos $400 \mathrm{~g} /$ plot dan dosis grand $\mathrm{K} 15$ g/plot (T2K3) yaitu 7,33 umbi/rumpun.

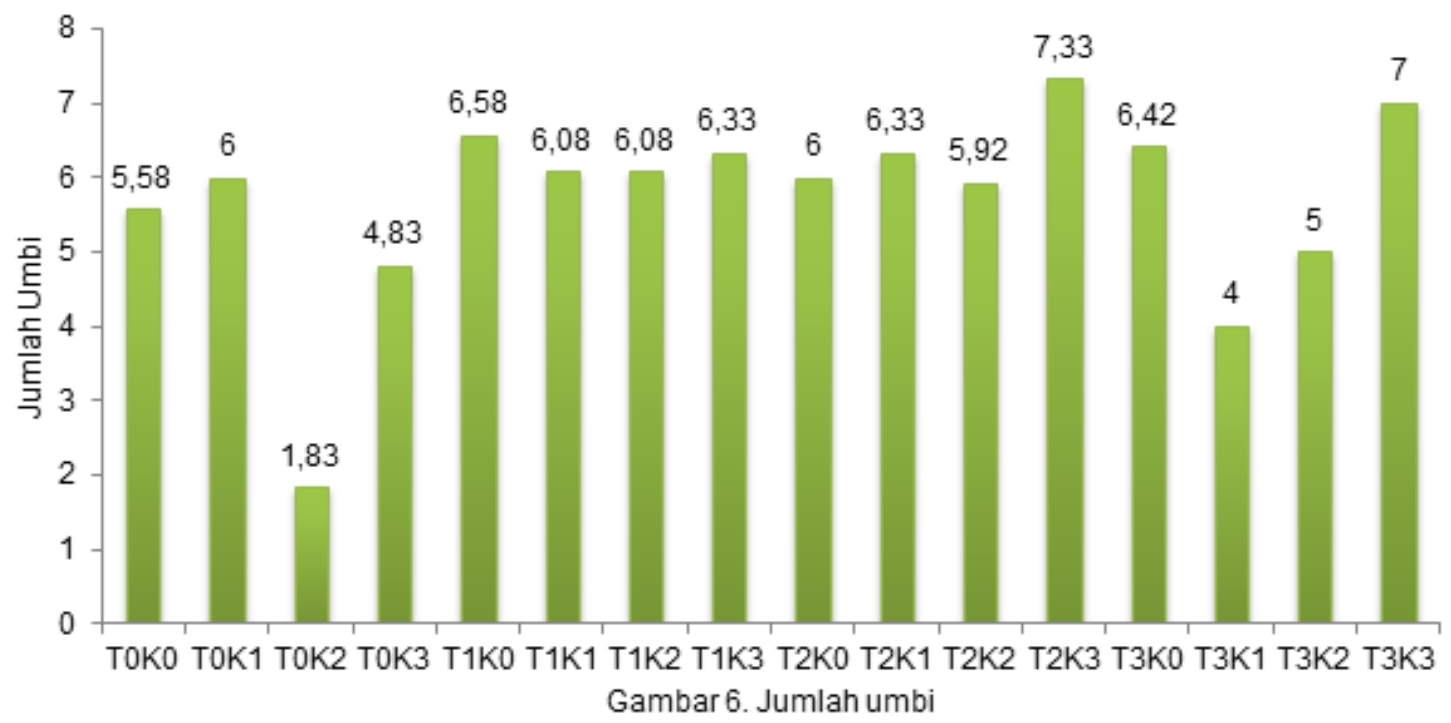

Pada kondisi lahan yang terendam, selama 30 hari tetapi tanaman masih dapat menghasilkan umbi dan tidak busuk, walaupun hasilnya kurang dari deksripsi. Hal ini dikarenakan trichoderma sp dicampur dengan pupuk kompos dapat menekan serangan penyakit pada saat tanaman terendam, seperti layu fusarium dan busuk umbi dan ditambah dengan pemberian pupuk grand $\mathrm{K}$ yang terbentuk dari senyawa lignin lebih tebal sehingga dinding sel menjadi lebih kuat dan dapat melindungi tanaman dari gangguan luar seperti ketahanan terhadap penyakit tertentu (Syakir dan Gusmaini, 2012), sedangkan menurut Ma'ruf dkk. (2019) bahwa Jumlah umbi yang dihasilkan oleh bawang merah juga 
dipengaruhi jumlah tunas lateral yang tumbuh dan mampu membentuk umbi baru, ditambah dengan pendapat Arman, dkk (2016) yang juga menyatakan bahwa jumlah umbi per rumpun lebih dominan dipengaruhi oleh faktor genetik (asal bibit yang digunakan) karena merupakan faktor yang mempengaruhi pertumbuhan tanaman serta jumlah umbi juga dipengaruhi oleh jumlah anakan per rumpun.

Trichoderma sp merupakan agen hayati antagonis yang berperan menekan aktivitas pathogen tumbuhan dari golongan

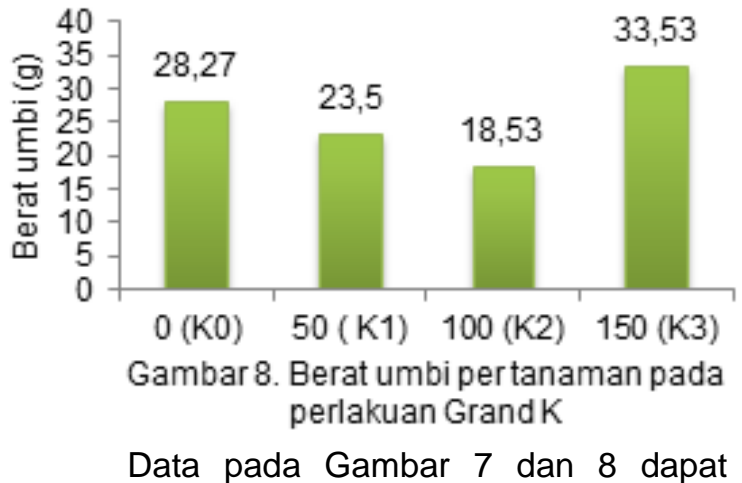
dilihat bahwa pengaruh utama Trichokompos nyata terhadap berat umbi basah per rumpun, dengan hasil terbaik pada Trichokompos 4 ton $\mathrm{ha}^{-1}$ dan grand $\mathrm{K}$ pada dosis $150 \mathrm{~kg} \mathrm{ha}^{-1}$. Hal ini menunjukkan bahwa proses pertambahan berat dipengaruhi oleh pemanjangan sel yang diikuti oleh pembesaran sel. Jika dibandingkan dari penelitian sebelumnya (Sutriana dan Raisa, 2019) yaitu $35,67 \mathrm{~g}$ memang yang dihasilkan ini tergolong rendah yaitu $31,93 \mathrm{~g}$, dan dibandingkan dengan hasil penelitian Sutriana dan Herman (2014) menjelaskan bahwa pada media tumbuh gambut mampu menghasilkan berat umbi per rumpun 53,60 g. Hal ini dikarenakan lahan gambut yang digunakan terendam banjir sehingga memperlambat atau menghentikkan proses pembesaran umbi bawang merah.

Menurut Sinaga dkk. (2013) bahwa penyebab suatu varietas beradaptasi dengan baik, yaitu varietas terdiri dari satu macam genotif yang mempunyai susunan genetik sedemikian rupa sehingga mampu mengendalikan sifat morfologi dan fisiologi yang dapat menyesuaikan diri pada lingkungan dan varietas terdiri dari sejumlah genotif yang berbeda, masing-masing mampu menyesuaikan diri terhadap perbedaan kisaran lingkungannya.

Ketersediaan unsur hara $(\mathrm{N}, \mathrm{P}, \mathrm{K})$ yang terkandung dalam kompos dan pupuk Grand K serta NPK yang diberikan memberikan respon yang positif terhadap pertumbuhan umbi, yang akan diserap dan jamur (Nurbalis dan Martinus, 2009). Menurut Bukhari dan Nuryulsen (2018), bahwa penggunaan trichoderma viridae dosis 40 g/lubang tanam dapat mengendalikan penyakit layu pada tanaman bawang merah.

\section{Berat Umbi Per Tanaman}

Hasil pengamatan terhadap parameter berat umbi per rumpun setelah dianalisis ragam menunjukkan bahwa pengaruh interaksi tidak nyata tetapi pengaruh utama berbagai dosis trichokompos dan pupuk grand $\mathrm{K}$ nyata.

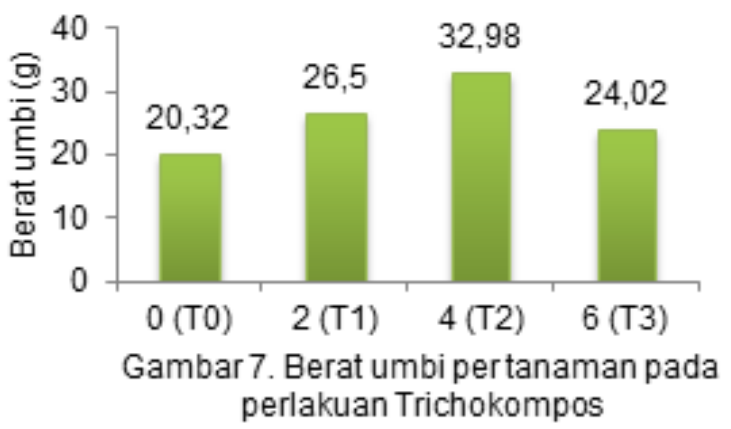

ditranslokasikan ke daun untuk diasimilasikan dalam proses fotosintesis. Salah satu hasil fotosintesis ini adalah fruktan, dimana fruktan sangat diperlukan untuk pembentukan umbi (Yetti dan Elitta, 2008). Tanaman Liliaceae menyimpan fruktan di dalam umbi (Salisbury dan Ross, 1995). Ini berarti yang mempengaruhi perbedaan pertumbuhan hingga produksi bawang merah selain faktor eksternal juga faktor internal yaitu genetik (bibit) yang digunakan.

\section{KESIMPULAN DAN SARAN}

\section{Kesimpulan}

1. Perlakuan terbaik pada dosis trichokompos 4-6 ton ha ${ }^{-1}$ dan grand $\mathrm{K} 150$ $\mathrm{kg} \mathrm{ha}^{-1}$

2. Bibit bima brebes merupakan bibit yang masih dapat bertahan dibuktikan dengan baiknya hasil yang diperoleh walaupun sudah terendam banjir 30 hari.

3. Lahan yang terendam menyebabkan penurunan hasil dan keterlambatan waktu panen.

4. Produksi rendah disebabkan oleh $80 \%$ populasi tanaman hilang yang diduga terbawa air hujan.

\section{Saran}

Dari hasil penelitian ini disarankan dalam budidaya tanaman bawang merah (Allium ascalonicum L.) pada lahan gambut rawan terendam menggunakan dosis 
trichokompos 4-6 ton ha ${ }^{-1}$ dan grand $\mathrm{K} 150 \mathrm{~kg}$ $\mathrm{ha}^{-1}$.

\section{Ucapan Terima Kasih}

Terima kasih disampaikan kepada Rektor Universitas Islam Riau melalui LPPM yang telah membantu biaya penelitian ini dalam skema Penelitian Internal UIR Anggaran tahun 2019, kepada Dekan Faperta, Prodi Agroteknologi, Bapak/lbu dosen serta mahasiswa Agroteknologi angkatan 2016 yang telah membantu di lapangan.

\section{DAFTAR PUSTAKA}

Arman, Z., Nelvia dan Armaini. 2016. Respons Fisiologi, Pertumbuhan, Produksi dan Serapan Bawang merah (Allium ascalonicum L) Terhadap pemberian Trichokompos Tandan Kosong Kelapa Sawit (TKKS) Terformulasi dan Pupuk $P$ di Lahan Gambut. Jurnal Agroteknologi, 6(2): $15-22$.

Azman, H dan Fifi. 2017. Pertumbuhan dan produksi Bawang Merah (Allium ascalonicum L.) dengan Pemberian Trichokompos Jerami Padi dan Kalium di Lahan Gambut. Jom Faperta Universitas Riau. 4(1): 1-15.

Bukhari dan S. Nuryulsen. 2018. Pengaruh pemberian Trichoderma sp. untuk mengendalikan penyakit layu fusarium pada beberapa jenis pisang di lahan yang telah terinfeksi. Jurnal IImiah Pertanian, 15 (1): $23-34$.

Ginanjar., H. Yetti, dan S. Yoseva. 2016. Pemberian pupuk Trichokompos jerami jagung terhadap pertumbuhan dan produksi bawang merah. JOM Faperta Universitas Riau. 3 (1): 1 - 11.

Ichwan. 2007. Pengaruh dosis Trichokompos terhadap pertumbuhan dan hasil cabai merah. Jurnal Agronomi 11 (1): 47-50

Ismawati., E Asni dan M.Y. Hamidy. 2012. Pengaruh Air Perasan Umbi Bawang Merah (Allium ascalonicum L.) terhadap Malondialdehid (MDA) Plasma Mencit yang diinduksi Hiperkolesterolemia. Jurnal Natur Indonesia, 14(2): 150-154

Ma'ruf, M., Nelvia., dan F. Silvina. 2019. Pengaruh Pemberian Pupuk Hayati dan Pupuk N, P, K Terhadap Pertumbuhan dan Produksi Tanaman Bawang Merah (Allium ascalonicum L.). Jurnal Agroteknologi, 10(1):9 - 14
Nurahmi, S dan Rina. 2012. Pengaruh Trichoderma Terhadap Perkecambahan dan Pertumbuhan Bibit Kakao, Tomat dan Kedelai. Jurnal Floratek 7: 57 - 65

Nurbalis dan Martius. 2011. Pemanfaatan bahan organic sebagai pembawa untuk meningkatkan kepadatan populasi Trichoderma viridae pada rhizosfir pisang dan pengaruhnya terhadap penyakit layu fusarium. Jurnal HPT Tropika. 11(2): $177-184$

Rochyat, E.A., Sundari dan Sumiati. 2017. Pengaruh Berbagai Olah Tanah dan Pemberian Pupuk Trichokompos Terhadap Pertumbuhan dan Hasil Bawang merah (Allium ascalonicum $\mathrm{L}$ ). Jurnal Magrobis 17 (2): $62-67$

Salisbury, F.B., dan Ross, C. W. 1995. Fisiologi Tumbuhan. Bandung: ITB Bandung

Sinaga, E. M., E.S. Bayu dan I. Nuriadi. (2013). Adaptasi Beberapa Varietas Bawang merah (Allium ascalonicum $\mathrm{L}$ ) di Dataran Rendah Medan. Jurnal Online Agroteknologi 1 (3): 404 - 417.

Sutriana, S dan Herman. 2014. Uji tiga varietas dan media tumbuh terhadap pertumbuhan dan produksi bawang merah (Allium ascalonicum L). Prosiding Seminar Nasional Agribisnis Universitas Islam Riau Pekanbaru, hlm. 250-255.

Sutriana, S dan Saripah. 2018. Uji Berbagai Dosis Trichokompos dan Komposisi Tanah Gambut Terhadap Peningkatan Produksi Bawang Merah (Allium ascalonicum L). Laporan Penelitian Universitas Islam Riau

Sutriana, S dan Raisa. 2019. Uji tingkat kematangan kompos terhadap produksi tiga varietas bawang merah (Allium ascalonicum L) pada tanah gambut. Jurnal Ilmiah Pertanian, 16 (1): 25 - 35

Syakir, M dan Gusmaini. 2012. Pengaruh penggunaan sumber pupuk kalium Terhadap produksi dan mutu minyak tanaman nilam. Jurnal Littri, 18 (2): 60 65.

Wahyunto., A. Dariah., D. Pitono dan Sarwani, M. 2003. Prospek pemanfaatan lahan gambut untuk perkebunan kelapa sawit di Indonesia. Perspektif 12(1):11-22.

Yetti, H dan E. Elita. 2008. Penggunaan Pupuk Organik dan $\mathrm{KCl}$ pada Tanaman bawang merah (Allium ascalonicum L). Jurnal Sagu 7 (1): $13-18$. 
Aplikasi Trichokompos dan Pupuk Grand-K Terhadap Bawang Merah (Sutriana, et al.) 